\title{
Land and agricultural commercialisation in Meru County, Kenya: evidence from three models
}

Cyriaque Hakizimana, Paul Goldsmith, Abdi Aralle Nunow, Adano Wario Roba and Jane Kathure Biashara

\begin{abstract}
What are the relative pros and cons of different pathways of agricultural commercialisation in Africa? This paper examines aspects of three commercial farming cases, each of which represents one of the three most dominant models of commercial agriculture - small-scale outgrowers, medium-size commercial farms and a large estate - in the high-potential area of Meru County in Kenya. The paper provides a comparative perspective across the cases, examining their outcomes in terms of land relations, labour, livelihoods and local economic linkages. The study used a mixed-methods approach, including a household survey and a range of qualitative methods including detailed life histories. We find diverse dynamics across our cases: increasing land consolidation spurred by the rising class of commercial coffee farmers, but also land fragmentation as a result of population pressure and prevalence of inheritance as a pathway to land acquisition in the case of horticultural outgrowers. The plantation generates relatively better paid employment for permanent skilled workers, while the commercial farms create employment for casualised, insecure and poorly paid seasonal labour. These labour regimes are highly gendered. The outgrowers combine family and hired labour. Across the three cases, farmers diversify income between on-farm and off-farm sources. The commercial and outgrower farms are dynamically integrated into the local economy, while the estate is less so. These features of the three models generate processes of social differentiation, which are reshaping the agrarian structure and rural economy in Meru County.
\end{abstract}

\section{Introduction}

What are the most effective forms of agricultural commercialisation in the African context? What balance of scale and capital intensity in agricultural investment is appropriate? What are the impacts on land, labour, livelihoods and economic growth of the different approaches to commercial agriculture? These are questions that have dominated the agrarian debate, not only in Africa, but also in many developing countries around the world (Jayne, Chamberlin, and Headey 2014). In the context of the contemporary 'land rush' in Africa (Hall, Scoones, and Tsikata 2015), such questions have re-emerged, with debates about alternative pathways of commercialisation, and the role of different farming 'models' (Smalley 2013). These debates are highly pertinent in highland Kenya, a region long seen as 
a site for agricultural commercialisation, from colonial times to the present (English, Jaffee, and Okello 2004).

Much of this debate is rather unhelpfully polarised, with some arguing for the efficiency of smallholder production (Delgado 1999; Lipton 2006), while others argue for large-scale, modernised commercial agriculture (Collier and Dercon 2014). Some point to emerging patterns of consolidation, and the importance of medium-scale farms (Sitko and Jayne 2014), while others argue for integration between estates and outgrowers through contract farming arrangements (von Braun and Meinzen-Dick 2009; World Bank 2011; Cotula et al. 2009; IFAD 2014). In this paper we do not attend to questions of farm size efficiency and factor productivity, but rather explore the varied agrarian dynamics - of land, labour, livelihoods and local economies - of different models of agricultural commercialisation in Kenya's Meru County. Based on these explorations, we argue that how models of agricultural commercialisation operate in practice is as much a function of their local and wider contexts and influences as of the accumulation dynamics implied by the model itself. Therefore, it is not a foregone conclusion which model of commercialisation produces more equitable land relations, generates quality jobs, enables sustainable livelihoods and underpins linkages into the local economy.

The relationships among the range of agricultural producers associated with different sizes and marketing models in Kenya has been central to the nation's agrarian transformation, and issues of agricultural organisation and scales of production have been the focus of policy debates over the decades. On-going processes of agrarian change in Kenya favour large consolidated farms over smallholders (Dolan 2004), and export-oriented commercial agriculture (Dolan and Humphrey 2000). The share of smallholders in the horticultural export sector, for instance, dropped from between 40 and 60 percent in the mid-1980s to about 18 percent in the late 1990s (Jaffee 1994; Dolan and Humphrey 2000). The Kenyan literature is divided on the implications of these changes. Elsewhere in Africa, poor smallholders who are squeezed out by the growth of large farms may find employment on large farms, as Maertens and Swinnen (2009) found in Senegal. However, smallholder outgrowers may be better off than workers on large farms, and structural changes that exclude outgrowers from accumulation opportunities can exacerbate rural poverty, as McCulloch and Ota (2002) found in Kenyan horticulture.

By analysing these cases of the three farming models in Meru County - a large estate, ${ }^{1}$ focusing on a mix of commercial cropping activities; medium-scale commercial coffee farming; and French bean contract farming - the paper explores the different outcomes for different people. We examine under what conditions the different models of agricultural commercialisation benefit different groups of people, and what impacts occur within the wider economy. We also examine the influence of the crop produced, and contextual

\footnotetext{
${ }^{1}$ We use the term 'estate' in this paper to refer to a large-scale mixed farming operation with on-farm processing, as this is the term widely used in East Africa. In the other countries in this study, we use the term 'plantation', which is the term more widely used in relation to tree crops and more generally in West Africa.
} 
factors such as differences in agro-ecology and demographic distributions, combined with local political economy factors.

The three models each have long historical precursors in Kenya's agrarian setting. Each has been shaped over time by politics and policy as well as markets. The categories of large, medium and small that are central to this study figure prominently in the current configuration of the Mount Kenya region's agriculture, and influenced the choice of Meru County as the site of the fieldwork. Meru encompasses almost all of Kenya's agro-ecological zones, themselves a primary determinant of the region's mix of agricultural, pastoralist and agro-pastoral production systems (Bernard 1972). For these reasons, the dynamics of historical change in Meru reflect the general process of commercialisation in Kenya's highlands.

This paper is structured as follows. A brief history of agricultural commercialisation in Kenya highlights longstanding debates in the Kenyan agrarian change literature, and explores these in general and in Meru County in particular. A definition and description of the three cases of farming models follows, together with an explanation of our methods and the types of data collected. This is followed by a discussion of the outcomes of the three farming cases - for land, labour, livelihoods and economic linkages - and, finally, we summarise our findings and their significance, and return to some of the key debates, in our conclusion.

\section{History of commercialisation in Kenya}

European intervention resulted in socioeconomic changes that reconfigured indigenous agriculture beyond recognition. The development of European settler agriculture, a primary driver of Kenya's colonial economy, depended heavily on the availability of land, labour and capital (Kanogo 1987). Slightly less than three million hectares of high-potential land in Kenya were allocated to European farmers by the colonial state to form the 'white highlands' (Kanogo 1987), and land alienation played an important role in the creation of rural labour markets vital for the colonial economy. The African highland reserves became sources of labour for European farms (Ndalilah 2012), although the pattern of recruitment varied across the country.

For the colonial administrators, exploiting the perceived tracts of unutilised land and availability of native labour enabled the introduction of new crops and technology in order to produce export commodities for the world market. The demarcation of the 'white highlands' and adjacent 'native reserves' dichotomised the agrarian structure, producing a dualism in patterns of land use and ownership in modern Kenya.

There were precursors to our estate, outgrower and medium-scale commercial farming cases in the colonial period. Meru was one of the three African reserved areas (along with Kisii and Embu) where cash crops were introduced before the land reform in the late 1950s. Coffee was introduced in Meru in the late 1930s, and tea in 1949 (Thurston 1987). A new class of indigenous accumulators, especially those educated by missionaries, emerged during the course of the colonial period. This petty bourgeoisie was comprised of teachers, preachers, 
supervisors, clerks and court interpreters who were employed by the colonial administration. In 1936 the colonial agriculture office initiated an experiment in indigenous coffee cultivation in the smallholder-dominated districts of Meru and Kisii. Native coffee production began slowly but steadily increased during the 1940s, and the coffee experiment was used to justify the legalisation of African participation in export crop production in 1954 .

This was calculated to insulate large settler farms from the political movement for land reform in Kenya by promoting linkages between these estates and local smallholders. The postindependence land redistribution proceeding under the Million Acre Scheme retained the same dualistic logic: settlement schemes ostensibly implemented to address the problem of landless peasants reserved the best land for a class of 'yeoman' commercial farmers who received 20-acre plots. Landless peasant farmers, in contrast, received smaller, eight-acre plots in ecologically marginal areas of the schemes (Leo 1984). Initiated in 1962, the scheme aimed to settle about 35,000 poor landless households on individual plots at a cost of about GBP 25 million, to be recovered from beneficiaries, but the scheme foundered on high levels of indebtedness among farmers, with the government threatening by the 1970 s to evict those who had not paid (Leo 1989).

The Kenya literature underscores a matrix of conceptual positions and empirical antecedents of the three types of commercial farming we investigate here. The strong Marxist theoretical orientation of earlier studies depicts the large-scale capitalist agricultural pathway of rural agrarian change in negative terms: the the primacy of large farms served to ensure that the economic interests of the native masses would continue to be of secondary importance after independence in 1963. A number of analyses follow the lead of Kitching (1980) in emphasising how this condemned rural producers to seek their livelihoods through labour migration or by combining subsistence cultivation with petty commodity production. This line of analysis culminated in the set of papers by Njonjo, Nganga, and Gutto published in the Review of African Political Economy often referred to as the 'Kenya peasant debate'. The publication in the same year of Colin Leys' influential study, Underdevelopment in Kenya (Leys 1975), provided analytical confirmation of the essentially top-down quality of Kenya's development, and set the stage for Appolo Njonjo's (1981) proclamation that Kenya's peasantry was doomed to 'become proletarians on patches of land'.

These arguments were instrumental in establishing Kenya as a primary exemplar of neocolonial policy in sub-Saharan Africa. The position of Leys and like-minded observers, however, began to erode as other evidence complicated interpretations of rural dynamics. Nicole Swainson's The growth of corporate capital in Kenya (Swainson 1980), for example, showed that, contrary to Leys' view, economic developments in Kenya were promoting the emergence of an African capitalist class. Collier and Lal (1984) showed that capital penetration in the form of cash cropping and off-farm labour was not the engine of inequality and marginalisation many analysts assumed it to be. Contrary to conventional assumptions of many neo-Marxist analyses, Kenya's rural 'reserves' benefitted via remittances generated by the urban-based 'metropolitan' economy. The role of off-farm 
income highlighted the widespread pattern of urban-rural 'straddling' (Cowen 1980). The colonial administration had accelerated processes of rural diversification by recruiting a corps of teachers, soldiers, supervisors, clerks and court interpreters who used their wages and official positions to accumulate land while employing hired labour (Ng'ang'a 1981).

Studies by Lofchie $(1986,1989)$ and Bates (1990) reassessed the role of markets and institutional arrangements to explain Kenya's agricultural success, offering a critique of the ideologically charged post-independence debate, and showing the diversity of forces at work in shaping class dynamics. Haugerud's (1989) research in Embu established that off-farm income was the single most important source of smallholder surplus accumulation. Smallholder commercialisation provided the means for reinvesting in other enterprises and the improvement of a household's human capital through education; off-farm income was in turn more dependable than volatile agricultural earnings. As Orvis (1993) observed for Kisii, differential access to off-farm employment and off-farm income became the primary differentiating factor. Those with off-farm employment invested in the expansion of family farming and educated their children to secure future off-farm incomes.

The high agricultural growth realised between 1960 and 1980 was driven by small-holder expansion under environmentally favourable conditions. By 1980, small-scale coffee producers had overtaken large estates in terms of value and quality despite the longer term frailties of the state institutions controlling coffee, tea and most other agricultural commodities such as cotton, and the bimodal agricultural policy framework favouring large producers over smallholders in general (Delgado 1999). Liberalisation, designed to increase efficiency and decrease state involvement in the economy, did not reverse the decline in agricultural production (Rono 2002).

Before the deterioration of the state-led model, the local cooperative society was a primary institution in Meru's rural landscape, and tea had joined the mix of crops such as coffee, potatoes, miraa ${ }^{2}$ and wheat that farmers referred to as success stories. The Meru Central Cooperative Union, with its maize-, coffee- and milk-processing facilities, was Meru's largest industrial plant. A combination of drought, high debt levels and declining returns prompted a makeover of the region's ranches; some of the white Kenya owners sold out, while others went into receivership (McCarthy 1999). The internal crises affecting both estates and peasant producers and disruptive developments of the post-1989 era effectively undermined state institutions' predominance in shaping Kenya's rural economy over the course of the century.

Liberalisation disrupted social relations and had an atomising effect on households, reinforcing women's contribution to farm labour while 'liberating' young men to participate in the non-farm informal economy (Lamont 1999). The rapid drop in Kenya's fertility rates signalled an important shift in rural household demography and internal household relations, with wider ramifications for class and agricultural surplus generation (Berry 1985). The changes also undermined the Meru version of the 'easily achieved pre-capitalist

\footnotetext{
${ }^{2}$ Miraa or khat is Catha edulis, a flowering shrub that contains cathinone and other stimulants and is widely used through ingestion in East Africa.
} 
capitalist synthesis' (Illife 1983, 39) that had contributed to the progress cited by Lofchie (1989) and others.

The entropy overtaking the state-led development process gave way to a new phase of commercialisation characterised by liberalisation and organisational change. Liberalisation increased uncertainty but also opened up new avenues for capital accumulation and rural livelihood diversification. The rise of the horticultural sector and expansion of smallscale dairying, for example, compensated for the decline of coffee and related problems in the tea sector. In Meru, the spread of contract farming enabled the shift by large numbers of smallholders into French beans and other horticultural crops. The number of smallholder contract farmers in horticulture has shrunk because of the European export ban due to unacceptable levels of chemical insecticides and the imposition of stricter export standards (English, Jaffee, and Okello 2004). This is, however, part of a larger sorting-out process dating back to the late precolonial period.

Shifts within Kenya's agricultural sectors have benefitted different groups of 'accumulators' at different times (Swainson 1980; Orvis 1993). The same dynamic is supporting the gradual emergence of middle farmers in the coffee sector, and to a lesser degree in the tea zones. The short 45- to 75-day production and payment cycle for French beans and other export vegetables is another indicator of the transitional dynamics, including the consolidation of rural class formation - not only emerging capitalist farmers and proletarians but also petty commodity producers - prevailing in Kenya's highlands. The growth of Meru production in general has been more a function of expansion than the intensification prerequisite for the growth in labour productivity called for by policy analysts. This helps explain why survey data discussed in the next section support Curry and Ray's (1985) observation that capitalist penetration of the countryside may create accumulating small producers without creating the landless proletariat featuring in the Orvis reassessment of the Kenya peasant debate. Some of them, though, may be characterised, following Curry and Ray (1985), as proletarians disguised as petty commodity producers.

The variety of large-, small- and medium-sized farming enterprises in Meru today is a direct consequence of this complex policy history in Kenya. This makes it an ideal case study to explore the outcomes and implications for contemporary processes of agricultural commercialisation.

\section{Study sites and research methods}

Meru County is located on the north-east slopes of Mount Kenya. Ecological zones range from the highlands (Meru Central and Meru North) with well-watered fertile soil and great agricultural potential to lowland semi-arid areas (Meru South and Tharaka), with altitudes ranging between 984 and 17,053 feet (300 to $5199 \mathrm{~m}$ ) (Dolan 2002). The average annual rainfall ranges from $380 \mathrm{~mm}$ in lowland areas to $2500 \mathrm{~mm}$ in the highland zones, with a bimodal rainfall pattern - March to May and October to December (Gakuubi and Wanzala 2012). Meru's population has dramatically increased, from 258,000 in 1948 to about 1.356 million in 2009, with a population density of about 195.5 people $/ \mathrm{km}^{2}$. The lowland areas 
are less densely populated (100 people $/ \mathrm{km}^{2}$ ) compared to the highland areas (400 people $/ \mathrm{km}^{2}$ ) (Dolan 2002).

The three farming-model case studies discussed in this paper are all located in the highland areas with altitude of about 17,053 feet $(5199 \mathrm{~m})$. The commercial and outgrower cases are situated in Meru Central and the plantation model is situated in Meru North (see Figure 1 and Table 1).

Our case study for the estate model is Kisima Farm, which is located in the Timau area in north-western Meru. The farm is about 6000 ha, and started as a family farm in the 1920 s for breeding Merino sheep. Cultivation on just 400 ha of the farm started in the 1940s. By the 1960s, approximately 50 percent of Kisima Farm's land was under cereal production (wheat, maize and barley). Diversification continued after the company was put under professional management in 1979, and the farm continues to specialise in cereals, while expanding production to certified potato seeds, horticulture and floriculture. Kisima Farm operates a substantial corporate social responsibility (CSR) programme, assisting the surrounding communities with education, healthcare, water development, agricultural extension and environmental sustainability, as discussed in more detail below.

Table 1. Main characteristics of case studies.

\begin{tabular}{lccc}
\hline Area & $\begin{array}{c}\text { Outgrower } \\
\text { Kithoka location }\end{array}$ & $\begin{array}{c}\text { Commercial } \\
\text { Equator area }\end{array}$ & $\begin{array}{c}\text { Estate } \\
\text { Timau area }\end{array}$ \\
\hline $\begin{array}{c}\text { Distance to Meru } \\
\text { town }(\mathrm{km})\end{array}$ & 14 & 17 & 34 \\
$\begin{array}{l}\text { Crop } \\
\text { Irrigation type }\end{array}$ & $\begin{array}{c}\text { Mrench beans } \\
\text { Micro sprinkler/spray irrigation } \\
\text { and flood irrigation } \\
0.5 \text { (mean) }\end{array}$ & $\begin{array}{c}\text { Coffee } \\
\text { Rain fed }\end{array}$ & $\begin{array}{c}\text { Cereals and horticulture } \\
\text { Pivot irrigation }\end{array}$ \\
$\begin{array}{c}\text { Land size } \\
\text { ownership (ha) }\end{array}$ & Labour intensive & $\begin{array}{c}\text { Labour } \\
\text { Mode of production }\end{array}$ & $\begin{array}{c}\text { Capital intensive and } \\
\text { highly mechanised }\end{array}$ \\
\hline
\end{tabular}

Source: Authors' compilation. 


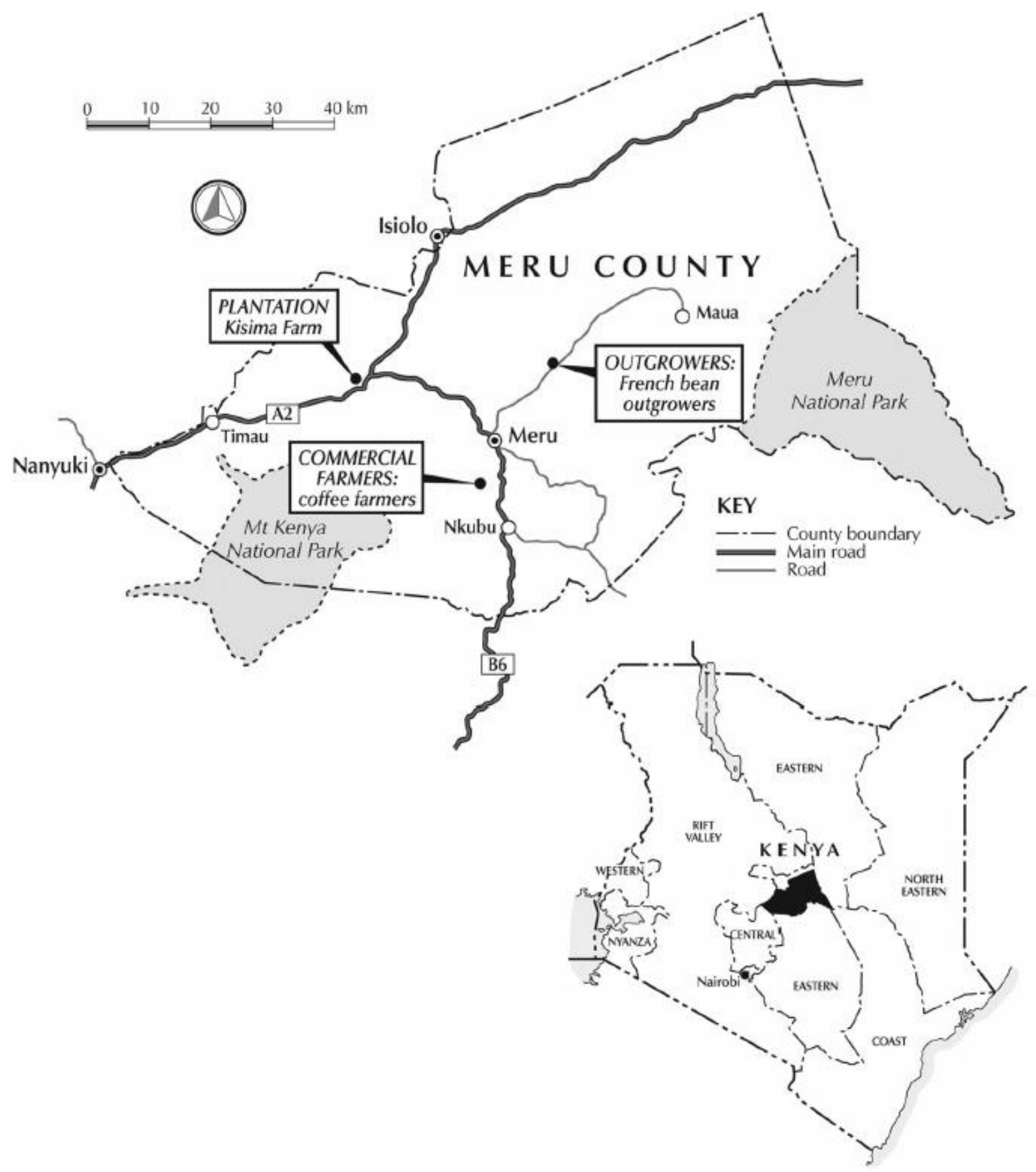

Figure 1. Location of farming models in Meru County.

The commercial coffee farms exist in a cluster to the south-east of Meru town, and there are a number of relatively large but not necessarily contiguous commercial coffee farms unevenly spread throughout Meru County. The Meru Coffee Board has records of 34 recognised commercial coffee growers in Meru, but this number significantly underestimates this sector, as it only includes those who own registered coffee factories. Based on our interviews and site visits, we estimate that there may be more than 250 commercial coffee farmers, at varying scales of production, in Meru. Commercial coffee farmers can be categorised into three groups, ranked in order of prevalence: full-time commercial coffee farmers; part- 
time commercial coffee farmers, such as civil servants and university employees who farm only on weekends or after business hours during weekdays; and absentee commercial coffee farmers who are mainly business people based in Nairobi. There is a lack of official data on the average number of coffee trees per commercial coffee farmer. Commercial coffee farmers in Meru also grow other crops including maize, potato, beans, sweet potato, banana, nuts and yams, and keep livestock, and some are also involved in agroforestry.

Our outgrower case study focuses on smallholder contract growers of French beans in Meru's Kithoka location. The average size of outgrower households' landholdings is about 0.5 ha and more than half ( 52 percent) reported that they allocate less than a quarter of their alreadysmall plots to contracted French beans. These are grown mostly by women, while men operate the rest of the plot where they grow other crops including maize, beans, coffee, sweet potato and potato, as well as engaging in off-farm activities. French bean contract farming operates on informal terms, based on mutual trust and casual verbal arrangements with companies, and is characterised by the absence of a binding, written contract. Meru Greens, Frigoken, VegPro and Finlays (formerly Homegrown) are the main companies involved in French bean contract-farming arrangements with outgrowers in Meru County. These companies specialise in French bean production for export and are based in Nairobi; they do not have nucleus estates in Meru but have instead established buying centres. The outgrowers get inputs such as seed and fertiliser from the contracting companies, which also provide extension services and sprayers. The price of beans is set before planting (at USD 0.29 per $\mathrm{kg}$ during the time of our fieldwork), and at the collection centre during the harvest the company deducts the value of $50 \mathrm{~kg}$ of beans for each unit $(0.25 \mathrm{~kg})$ of seeds provided to the contract farmer at the start of the season. The farmers deliver the French beans at their own cost to the collection centres, where the beans are sorted, graded, weighed and assessed for quality before being transported to Nairobi. The waiting period for payment is about two weeks.

The research design and methods of this study are elaborated in some detail in the introduction to this JPS Forum (see Hall, Scoones, and Tsikata 2016). Here, we explain how this design and set of methods were operationalised in our case studies in Kenya. In-depth interviews were conducted with key informants in the county government, with commercial farmers, farm managers, farm workers, outgrowers and traders, and were complemented with other qualitative methods including gathering of key documents and participant observation. Findings were used, together with findings from Ghana and Zambia, to inform the design of a household survey, which was administered by the researchers together with assistants in the second half of 2014. The sample households were drawn from the communities surrounding each of our three cases. An estimated number of households resident within a five-kilometre radius of the centre point of each case study was obtained from the local authorities; this was then divided by 100 (our desired sample size) to obtain a sampling interval that we used to sample the households that participated in the study. While this method worked perfectly well for data collection for both the estate and outgrower models, the dispersed nature of commercial coffee production made its application difficult in our third case study. Accordingly, we sampled 19 households within a one- 
kilometre radius of six of the commercial coffee farms. For life-history interviews, we selected households purposively, to ensure inclusion of those involved in our case studies as farmers and workers, and those not involved but living within the focal area. Table 2 gives details of our sample.

Table 2. Sample households.

\begin{tabular}{lccc}
\hline Farming model & $\begin{array}{c}\text { Number of } \\
\text { households }\end{array}$ & $\begin{array}{c}\text { Number of household } \\
\text { members }\end{array}$ & $\begin{array}{c}\text { Total number of life-history } \\
\text { interviews }\end{array}$ \\
\hline Plantation & 109 & 398 & 22 \\
Commercial & 116 & 468 & 17 \\
$\quad$ farm & 108 & 395 & 17 \\
Outgrower & 333 & 1261 & 56 \\
Total & & & \\
\hline
\end{tabular}

Source: Authors' compilation.

\section{Land: a heterogeneous peasantry - coexistence of landed and (semi)landless classes}

As noted earlier, there is growing pressure on land in Meru County. Parallel processes of land fragmentation and consolidation have affected the different cases of farming models and their patterns of accumulation in different ways. Amongst smallholders, some of whom allocate a portion of their land to contract farming, there is increasing land fragmentation. This is caused by the inheritance system, as land is divided across generations. The majority of the households in all three focal areas acquired land through inheritance $(78.8,86.9$ and 86.2 percent in estate, outgrower and commercial focal areas, respectively). Landlessness is virtually non-existent in all three focal areas, although the average land size is relatively small (0.6, 0.5 and 0.8 ha per household for the estate, outgrower and commercial focal areas, respectively) and is less than half of the average land size at the county and national levels (1.7 and 1.8 ha per household, respectively). The area where people are most likely to have acquired land through purchase is in the commercial coffee farming area (10.3 percent). Land fragmentation is exacerbated by the lack of financial capital to acquire land through the market. Across all three cases, less than 10 percent of households surveyed have bought land. The household survey depicts a general perception among respondents across the three cases (79.4, 82.4 and 82.8 percent for the estate, outgrower and commercial focal areas, respectively) that land availability has been declining over time, while the price of land continues to increase (89.7, 97.4 and 95.4 percent for the estate, outgrower and commercial focal areas, respectively).

Although data on rental rates are not readily available at the county level, our fieldwork interviews show that one hectare may be rented at about USD 146 per annum. In-depth and life-history interviews reveal that women who are engaged in contract farming also have casual employment and use their incomes from this wage work to lease small plots of land (less than $0.25 \mathrm{ha}$ ) on an annual basis, mainly from relatives, to grow French beans that 
they sell on contract. The area surrounding Kisima Farm that experienced land reform five decades ago is also affected by acute land fragmentation that is gradually causing dispossession, particularly for the younger generation.

In contrast, life histories reveal that among those involved in commercial coffee growing, there has been a process of land consolidation and accumulation, with some mediumscale farms emerging, often with scattered plots purchased from indebted households or struggling smallholders who fail to cope with shocks such as illness or death in their households. All of the commercial coffee farmers in our study have access to substantial offfarm income streams and reported that they acquired their farms through the local land market as 'accumulators'. One male commercial coffee farmer reported that he bought six farms of different sizes between 1990 and 2012. A female commercial coffee farmer reported that she bought two farms between 2007 and 2013. In all areas, the lack of available land except for those who can afford to buy it means that young people are increasingly 'stepping out' of agriculture or are combining farming and wage employment. In the area surrounding the estate, for instance, our life-history interviews show that younger people are combining their small inherited plots with wage employment at Kisima Farm. Many people across all sites migrate to urban centres or estates to sell their labour.

Our study shows, therefore, how dynamics in land ownership and control continue to change, and are driven by different patterns of accumulation. While the basic patterns of land use and ownership were set in the colonial era through the expropriation of large farms, such as the Kisima estate, and through post-independence land reform, such as the Million Acre Scheme, there is a continuing dynamic characterised by both consolidation and accumulation, and fragmentation and dispossession. This has important implications for the patterns and possibilities of commercial agriculture in Meru. As in colonial times, as noted by Haugerud (1989) and Orvis (1993), off-farm income remains a key determinant for land accumulation strategies locally. Households that have access to substantial off-farm income streams are investing in agriculture through buying land to become commercial farmers, notably the coffee farmers. By contrast, others continue on a downward path towards landlessness due to increasing land fragmentation, through inheritance, as is evident among the outgrowers and in the vicinity of the estate. While the Million Acre settlement scheme near Kisima has offset this to some degree, land pressures are currently being felt by the younger generation. The descendants of 'accumulators' from the colonial era (as observed by Swainson 1980) are highly educated and are among those who now hold senior positions as public servants or in tertiary education. They form part of a new class of land accumulators, exemplified by the commercial coffee farmers in our study. By contrast, farm workers working on Kisima Farm or employed by commercial coffee farmers are often the children of 'peasant-worker' households and continue to survive by combining farming and often-fragile, poorly paid wage employment, as their parents did. Land ownership is also highly gendered, with most land being held formally by men. 


\section{Labour: scale and quality of employment are highly diverse across the three farming models}

Large-scale estates, as well as commercial farms, are seen by some as important sources of employment in agriculture (Collier and Dercon 2014; Ariyo and Mortimore 2011), moving people from peasant or petty commodity production to a labouring class (Hayami and Otsuka 1993; Adagala 1991; Lincoln 1994). This may provide opportunities for some, but employment impacts in commercial agriculture are highly variable, with differences in wages and conditions across different crops (Richardson 2010; Smalley 2013), and often extremely gendered (Dancer and Sulle 2015; White and White 2012; Oya 2010; Mate 2001). Across our models, we explored the employment impacts of the different models on surrounding households.

Smalley (2013) argues that the employment effects of estate and commercial agriculture models may not differ in any meaningful way because they tend to face similar challenges relating to the costs of production in terms of scale and intensity. However, we find differences in the employment patterns in our two cases, due to contextual factors, and so guard against generalisation. We found that our case of a highly mechanised and vertically integrated estate created more permanent jobs than the medium-scale commercial farms did, while the latter had poorer quality jobs compared to the former. While Kisima Farm creates about 0.1 permanent worker jobs per hectare and about half that number for casual workers, we found that the commercial coffee farms in our sample created about 6.7 casual worker jobs per hectar - but fewer permanent jobs owing to the seasonality of the work required.

The estate, however, generates more permanent employment than the medium-scale commercial farmers and the outgrowers, both of which have created more casual employment. Commercial coffee farmers indicate that they do not need permanent workers because their coffee production is seasonal. In contrast, the highly mechanised estate is able to sustain year-round farming operations using sophisticated production methods that are unaffordable for the small or medium producers with limited capitalisation. According to the management at Kisima Farm, permanent workers constitute almost three-quarters (73.8 percent) of its workforce. The company seems to have resisted the current tendency towards labour casualisation observed in the large-scale farming sector (Smalley 2013). Driven by its ambitions to remain competitive in both national and international markets, Kisima Farm continuously upgrades its operational systems, but at the same time ventures into niche markets such as potato-seed production and on-farm processing of canola oil. Its success relies heavily on its ability to retain a capable and productive workforce. According to a senior manager, Kisima's labour-retention strategy consists of providing job security and good working conditions for its best-performing employees.

We distinguish between working conditions on the estate, which appear satisfactory, and the challenges of social reproduction for farm workers. The benefits received by permanent workers at Kisima Farm include on-farm housing with water supply and electricity, or a 
housing allowance for off-farm permanent employees; up to $15 \mathrm{~kg}$ of subsidised wheat flour per month that the company sells to permanent workers at USD 0.19 per $\mathrm{kg}$ (the normal market price is USD $0.53 / \mathrm{kg}$ ); one litre of milk a day; and free healthcare services. While there are no major grievances around working conditions among on-farm permanent workers, there is widespread concern about social reproduction on the farm. They complain, for instance, about the absence of a school on the farm and the refusal of the company to provide transportation for their children who have to travel a long distance to go to school. In contrast to the conditions of permanent workers on the estate, conditions for casual workers across the three farming models are similar and tend to be poor. Casual employment can last between a few days and six months at the estate and on the commercial farms. Outgrowers use casual workers mainly for harvesting which can last for about two weeks because of the small size of the plots, while relying on family labour and selfemployment at other times. Only a third of the total outgrowers (30 percent) in our sample reported that they have used hired labour to produce French beans, and about 67.9 percent relied mostly or entirely on their household labour. Also, wages for casual workers are similar across the cases and are generally below the minimum wage in the agricultural industry in Kenya (USD 3.33 per day). Kisima Farm pays casual workers USD 2.59 per day. Some commercial farms offer daily rates of about USD 2.43 or piece-work at a rate of between USD 0.05 and USD 0.06 per kilogramme of picked coffee cherry and USD 0.10 for each pruned coffee tree. Outgrowers pay casual workers a daily rate of about USD 2.43 for harvesting. In contrast, Kisima Farm's wage rates for permanent workers range from USD 80.70 per month to USD 291 per month, depending on their level of skill. Even the minimum salaries for Kisima Farm's permanent workers are above the average wage for casual workers (USD 62.17 per month) across the three farming models and above the minimum wage (USD 65.78 per month).

In summary, medium-scale commercial coffee farms employ more people per hectare, but the employment that they generate is highly casualised, seasonal, insecure and poorly paid. By contrast, outgrowers rely mostly on family labour, with some hiring temporarily and on poor wages. Finally, the estate employs more permanent, skilled workers and offers better employment conditions, though not to casual workers. Our findings challenge the depiction of estates as generating substantial employment (Collier and Dercon 2014) and indicate that commercial farms produce far more jobs per hectare than the estate we studied, though we acknowledge that this is only one case and that labour intensity is shaped by production technologies as well as scale.

\section{Livelihoods: diversification across wage work and farming, and uneven food security}

What are the consequences for livelihoods of the different types of engagement with commercial agriculture? Much of the literature highlights the benefits of on-farm employment, especially for land-poor households (Maertens and Swinnen 2009, for Senegal), while some promotes an outgrower model, which allows continued access to land while engaging with high-value production (World Bank 2011; Cotula et al. 2009). For Kenya, McCulloch and Ota (2002) found that outgrowers involved in horticultural production are, on 
average, substantially better off than those not involved in contracting, including those employed on large farms. They argue that outgrowers are more likely to accumulate wealth as they are able to benefit from higher prices, and can gain access to credit and inputs. This is especially important for women (Velte and Dannenberg 2014; Dolan 2001).

We understand engagements with commercial agriculture, including employment and outgrowing, within the context of wider livelihood strategies. For example, most outgrower households surveyed allocate only a small portion of their land to the contract crop. Those contracting tend to be women who engage in commercial farming with very limited resources, very often leasing small plots of land from their extended family members or neighbours, using the income that they obtain from selling their labour as casual labourers or taking small loans from their small, informal saving groups, in order to support their households' income. In relation to overall household activities, this is a small element, although important for the women involved. However, opportunities for significant accumulation are limited, and such smallholders often have a diversified portfolio of livelihood activities, including other cropping and livestock production activities as well as off-farm work. Equally in relation to employment, relatively few have access to well-paid skilled employment. Those who do, especially those working at Kisima, report improved livelihood outcomes - partly through good wages and other benefits, including food packages. However, most people in our study areas are reliant on low-paid, unskilled jobs, in casual or temporary employment. Among these groups, livelihoods are precarious.

As discussed earlier, this has a gendered dimension. While temporary and poorly paid, access to casual labour for women can be vitally important, providing a separate stream of income that can be combined with other farming and reproductive activities. Most workers are also farmers, and the links between own-farm production and employment on Kisima Farm or commercial coffee farms are important in a diversified livelihood. In fact, only the migrant labourers who live in the labour camps on Kisima Farm have been fully proletarianised, and they report enormous difficulties in leasing land in the local area. In contrast, in-depth interviews and life histories show that the commercial coffee farmers are investing significantly in the education of their children in tertiary education, developing high-quality properties, diversifying via both on- and off-farm investments and extending their land holdings.

Another element of livelihoods we explored in our study was self-reported food security. We found a higher percentage of food insecurity in the outgrower area compared to the other two cases. Asking about the frequency of household members skipping meals due to not having enough food over the past 12 months, we found about one-quarter of respondents across all three focal areas $(23.4,25.9$ and 26.9 percent for estate, commercial farms and outgrowers, respectively) said they had skipped meals 'some of the time'; while 17.8, 19.4 and 10.3 percent in estate, outgrower and commercial farming area, respectively, reported 'seldom or rarely' doing so. Relatively higher percentages of households living in estate and commercial farming area (58.9 and 63.8 percent, respectively) reported that they have 'never' skipped meals, in comparison to those living in the out-grower area (52.8 percent). 
While this is a limited measure of food security, this indicator provides a basis for further investigation of possible linkages between commercial agriculture models and food security.

Overall, the ability of some households to combine production on their own land with wage employment was central to their ability to achieve adequate livelihood outcomes. This was particularly notable among the outgrowers, many of whom engaged in wage work elsewhere while also hiring in labour. But sustaining adequate livelihood outcomes is very different from accumulating, and the commercial farmers, in contrast, had more robust livelihood outcomes based not only on diversification on-farm but, as Orvis (1993) showed in his study of livelihood strategies and accumulation pathways, through a wide array of off-farm activities, incomes from which are invested in expanding their farming operations.

\section{Local economic linkages: stronger with outgrowing and commercial farming than from the estate}

A key debate in the literature centres on the extent and ways in which different types of agricultural commercialisation forge local economic linkages (Oya 2007; Li 2011; Davies 1987; Lele and Agarwal 1989; Papenfus 2000; McCarthy 2010; see also Hall, Scoones, and Tsikata 2016). Thus, commercial enterprises dealing with local suppliers and processors and employing locally are more likely to generate local economic spin-offs, whereas 'enclave' enterprises, separated from the local economy, such as estates, will have fewer such linkages (Smalley 2013).

Our findings corroborate these patterns observed elsewhere. For example, Kisima Farm relies heavily on multinational agribusiness companies for input procurement and links to big national players for selling farm products, with the exception of its potato-seed project that supplies local smallholders, and a variety of CSR initiatives that are not central to its business operations. ${ }^{3}$ Yara, the multinational agribusiness company, is the major supplier for key farm inputs such as fertiliser and other chemicals. Seeds for wheat and barley are sourced from Kenya Agricultural and Livestock Research Organisation (KALRO) based in Nairobi, while the seeds for flowers are procured from Naivasha, about $265 \mathrm{~km}$ away. Irrigation equipment and other farm implements are also sourced from Nairobi. Labour is sourced across Meru County and from neighbouring regions. The major buyer of the barley produced by Kisima Farm is Kenya Breweries Ltd based in Nairobi, while wheat is sold to major millers in Nyeri about $135 \mathrm{~km}$ away and its flowers are auctioned in Amsterdam. Thus, both backward and forward linkages are mostly outside the local economy, and the farm operates as a high-value 'enclave' largely delinked from local markets.

In contrast, the commercial coffee farms are quite dynamically integrated into the local economy: these farmers buy fertiliser and insecticide in bulk from farm-input distributors in Meru town and procure seedlings from the local Mariene Coffee Research Centre. They also source equipment for their coffee factories, as well as transport services, from Meru town, and labour is sourced locally from adjacent villages. Some post-harvest processing tasks, such as pulping and drying of coffee beans, takes place manually on the farms, and 
contributes to deepening the local economic linkages via wages. However, farm output markets are not local; farmers sell to millers in Nairobi and the finished product is auctioned at the Nairobi Coffee Exchange.

While the outgrowers have the strongest and most localised economy linkages, the extent of economic linkages is modest because of the scale of their production. Farmers buy small quantities of seed (for crops other than French beans) and other inputs for their own onfarm crop production from local 'Agrovet' shops. These local dealers in turn source their products from larger agro-input distributors in Meru town, who source their products from Nairobi. The outgrowers supply French beans to the local collection centres where the crop is sorted and graded before it is transported to the contracting companies' headquarters in Nairobi where French beans are then washed, packaged and exported to the European market. Due to the informal character of outgrowing arrangements, they also sell in local spot markets. Outgrowers use local transport services and hire labour locally. Therefore, compared to the other two farming models, the outgrower model tends to generate more substantial local economic linkages in input acquisition as well as marketing the produce, and yet their overall impacts are limited by the scale of production.

In terms of linkages based on consumption and expenditure, there are further contrasts between the three commercial farming cases. Food was the first expenditure priority for households across our samples in all categories. Households with permanent workers at Kisima Farm buy food farther afield, compared to all other groups, as they have more income and can afford the transportation costs to do their shopping in the surrounding main commercial centres, such as Meru and Nanyuki. They also remit more than other households, as many of them come from outside the area. They invest their wages in smallholder farms in their home areas, which are often managed by relatives to whom they send money every month.

Local economic linkages vary across commercialisation models, with the loose and flexible outgrower arrangement being the most embedded in the local economy. Coffee growers also have multiple economic linkages, and their greater commercial activity generates greater demand for labour, inputs and services. By contrast, Kisima Farm operates largely as an 'enclave', connecting to distant input and output markets, and often employing permanent staff from farther afield, mainly from other areas in Meru County and other surrounding counties.

\section{Conclusion}

This study set out to investigate the varied outcomes of three examples of commercial farming models - estate, medium-sized commercial farming and outgrowers - in Kenya's Meru County. The results show how land access, employment opportunities, livelihood impacts and linkage effects in the local economy differ significantly across the cases. However, these findings are very context specific and we do not make wider claims or generalise our findings from this limited study. Meru County, with high population densities and land 
pressures, highlights distinct dynamics of agrarian change within which these different commercialisation pathways must be understood.

The commercial farmers and the estate present potential for creating rural employment and enhancing rural livelihoods. In addition, the estate generates relatively better paid skilled jobs for permanent on-farm workers, while the commercial farms create employment for casualised, insecure and poorly paid seasonal labour. The outgrowers, operating in the absence of a nucleus estate, combine hired labour, family labour and self-employment for their production. The study reveals wage differentials between the models and between women and men within each model. While permanent workers in the estate model are the best paid, the male casual workers are better paid than their female counterparts across the three cases. The estate is poorly integrated into the local economy and shows weak local economic linkages, as opposed to both the commercial and outgrower farms, which are quite dynamically integrated into the local economy. The results show an emerging pattern of agricultural production, linked to processes of land and social differentiation in the study area. This has implications for agrarian structure and rural economy in Meru County, as well as in other high agricultural potential areas in Kenya.

Contrary to the characterisation of estates (Hayami and Otsuka 1993; Adagala 1991; Lincoln 1994), in our case the estate has not dispossessed people in recent times, nor produced landlessness that has forced people to sell their labour. While new acquisitions of estates may well unleash such processes, our study corroborates the literature that argues the expansion of commercial farms may, in the long run, also disrupt the local agrarian production as the commercial coffee farmers buy local small farms and push local households into landlessness (Amanor and Pabi 2007; Amanor 2011). This is most evident in the mediumscale commercial farming area, and may eventually cause a decline in local food production with local people starting to rely more and more on wage labour.

Commercial coffee growing is accompanied by a process of land consolidation, and accumulation driven by access to external sources of income, notably from off-farm professional jobs. This is generating employment, much of it casual and temporary, and operations are embedded in the local economy. In contrast, the outgrowers in our sample were not accumulating significantly, as their contracted crop area was limited. Employment effects were also limited, as outgrowers rely mostly on family labour, with only some hiring in labour and this only for particular tasks.

Unlike traditional outgrowing arrangements that tend to grow only one crop sold on contract, farming contracted crops in our study is combined with a variety of agricultural and off-farm activities in a flexible livelihood portfolio. Opportunities from outgrowing, however, are significant for some, especially women who have gained incomes in their own right, and are able to lease land to extend their farming activities as a result. In all three study areas, there is a growing pattern of land fragmentation, as some drop out of farming or dispose of parcels of land. This results in a growing, although still partial, proletarianisation, as people must combine farming on very small plots with wage labour 
elsewhere, including on commercial farms and estates, a pattern similar to those observed by Curry and Ray (1985). While our findings support some aspects of Njonjo's (1981) theory of 'proletarians on patches of land', they also show that his argument does not capture the full range of independent petty commodity producers who are successfully producing for the market and are not necessarily engaging in rural wage employment.

The agrarian structure and patterns of land holding reflect in large part the inheritance of the colonial pattern of land appropriation and subsequent attempts at redistribution. Flows of labour in particular across these types of farms are important, as people seek temporary, casual work to supplement their incomes. Land acquisition by commercial farmers, through injections of finance from outside the area, results in further land sales. An evolving class differentiation with different opportunities for accumulation is observed across the area, with shifting categories of peasant, worker-peasant, petty commodity producer and rural bourgeoisie being created. This has a gender and age dimension, as women find opportunities for independent income as outgrowers or labourers, while youth increasingly join farm workforces, both in the estate-type farms like Kisima and increasingly large consolidated commercial farms.

The findings of our study, limited as it is, suggest that the outcomes of different forms of commercialisation of agriculture may be highly varied; dependent on changing agrarian relations, class formation and gender dynamics; and in turn influenced by historically defined geographical patterns of land use and ownership, and the interactions between different types of farms, operating at different scales. Our three cases from Meru show how there are different winners and losers, and that the agrarian setting is undergoing change, influenced by both local factors and wider influences, ranging from government policies to international export commodity prices.

While the debates of the 1970 and 1980 s centred on the future of the peasantry - either as an emergent African capitalist farming class or as proletarianising fractions of labour - we find both visions of the future evident in Meru. In all focal areas we studied, and particularly surrounding the estate and among the outgrowers, households compose their livelihoods via their own petty commodity production combined with wage labour, as Kitching (1980) argued. Yet among the coffee farmers we find dynamics of accumulation and differentiation, with a significant capitalist class emerging (Swainson 1980), dynamics that are being driven by access to off-farm incomes, as envisaged by Haugerud (1989) and Orvis (1993). However, our findings do not support Orvis's $(1993,35)$ prediction that the growth of this emerging capitalist class is most likely to be constrained by the rising land prices that will restrain this class from accumulating land in any significant quantity, a phenomenon that he predicted may reverse this process of accumulation and revert this class, in the long run, to peasant-worker households. Access to significant off-farm income remains a main differentiating factor as in the past, and the current social differentiation is also driven by highly diverse labour arrangements in different models and dynamic interaction between capitalist smallholders and medium-scale commercial farmers. Whether or not the Kenyan peasantry's future is that of 'middle farmers' or 'fractions of labour', therefore, appears to be 
the wrong question; our study suggests that, in our cases in Meru, it is both. The precise underpinnings of these processes of differentiation, and the ways in which these class relations evolve, are issues for further study.

\section{Acknowledgements}

The authors would like to acknowledge the contribution and support of the principal investigators, reviewers and field assistants.

\section{Disclosure statement}

No potential conflict of interest was reported by the authors.

\section{Funding}

This research project was jointly funded by ESRC and DFID under the ESRC-DFID Joint Poverty Alleviation Programme [grant number ES/Jo1754X/1]. 


\section{References}

Adagala, K. 1991. Households and historical change on plantations in Kenya. In Women, households and change, eds. E. Masini and S. Stratigos, 206-241. Tokyo: UNU.

Amanor, K.S. 2011. Global land grabs, agribusiness and the commercial smallholder: A west african perspective. Paper presented at the International Conference on Global Land GrabbingICGLG, Institute of Development Studies, University of Sussex, 6-8 April.

Amanor, K.S. and O. Pabi. 2007. Space, time, rhetoric and agricultural change in the transition zone of Ghana. Human Ecology 35, no. 1: 51-67.

Ariyo, J.A. and M. Mortimore. 2011. Land deals and commercial agriculture in Nigeria: The New Nigerian farms in Shonga District, Kwara State. Paper presented at the international conference on global land grabbing, Institute of Development Studies, University of Sussex, 6-8 April.

Bates, R.H. 1990. Beyond the miracle of the market: The political economy of agrarian development in Kenya. Cambridge: Cambridge University Press.

Bernard, F.E. 1972. East of Mt. Kenya: Meru agriculture in transition. Munich: Veltforum Verlag.

Berry, S. 1985. Fathers work for their sons: Accumulation, mobility, and class formation in an extended Yoruba community. Berkeley and Los Angeles: University of California Press. von Braun, J. and R. Meinzen-Dick. 2009. "Land grabbing" by foreign investors in developing countries: risks and opportunities. IFPRI Policy Brief no 13. http://ebrary.ifpri.org/cdm/ref/ collection/p15738coll2/id/14853.

Collier, P. and S. Dercon. 2014. African agriculture in 50 years: Smallholders in a rapidly changing world?. World Development 63: 92-101.

Collier, P. and D. Lal. 1984. Why poor people get rich: Kenya 1960-1979. World Development 12, no. 1: 1007-18.

Cotula, L., S. Vermeulen, R. Leonard, and J. Keeley. 2009. Land grab or development opportunity? Agricultural investment and international land deals in Africa. London/Rome: IIED/FAO/IFAD. Cowen, M. 1980. Commodity production in Kenya's central province. In Rural development in tropical Africa, ed. J. Heyer, P. Roberts, and G. Williams, 121-142. London: MacMillan.

Curry, K. and L. Ray 1985. Class formation within the peasantry: Recent theoretical Developments in the analysis of the peasantry with specific reference to the East African debate. Sociology 19, no. 4: 573-85.

Dancer, H. and E. Sulle. 2015. Gender implications of agricultural commercialisation: The case of sugarcane production in Kilombero district, Tanzania. Working Paper No. 118. Future Agricultures. http://www.plaas.org.za/sites/default/files/publicationspdf/FAC_Working_Paper_118.pdf.

Davies, S. 1987. Plantations and the rural economy: Poverty, employment and food security in Kenya. IDS Bulletin 18, no. 2: 15-20.

Delgado, C. 1999. Sources of growth in smallholder agriculture in sub-Saharan Africa: the role of vertical integration of smallholders with processors and marketers of high-value items. Agrekon, May special issue: 165-189.

Dolan, C. 2001. The 'good wife': struggles over resources in the Kenyan horticultural sector. The Journal of Development Studies 37, no 3: 39-70. 
Dolan C.M. 2002. Encyclopedia of world cultures supplement. http://www.encyclopedia.com/places/ africa/kenyan-political-geography/meru

Dolan, C.S. 2004. On farm and packhouse: Employment at the bottom of a global value Chain. Rural Sociology 69, no. 1: 99-126.

Dolan, C. and J. Humphrey. 2000. Governance and trade in fresh vegetables: The impact of UK supermarkets on the African horticulture industry. Journal of Development Studies 37, no 2: 147-176. English, P., S. Jaffee and J. Okello. 2004. Exporting out of Africa: Kenya's horticulture success story. Case Study from the Scaling Up Poverty Reduction conference, 25-27 May 2004, Shanghai. http://info.worldbank.org/etools/docs/reducingpoverty/case/120/fullcase/Kenya2OHOR TICULTURE2OFull\%20Case.pdf.

Gakuubi, M.M. and W. Wanzala. 2012. A survey of plants and plant products traditionally used in livestock health management in Buuri district, Meru County, Kenya. Journal of Ethnobiology and Ethnomedicine 8, no. 39: 1-19.

Hal , R., I. Scoones, and D. Tsikata, eds. 2015. Africa's land rush: rural livelihoods and agrarian change. Oxford: James Currey.

Hall, R., I. Scoones, and D. Tsikata. 2016. Plantations, Outgrowers and Commercial Farming in Africa: Agricultural Commercialisation and Implications for Agrarian Change. Journal of Peasant Studies. http://dx.doi.org/10.1080/03066150.2016.1263187

Haugerud, A. 1989. Land tenure and agrarian change in Kenya. Journal of the International African Institute 59, no. 1: 61-90.

Hayami, Y. and K. Otsuka. 1993. The economics of contract choice: An agrarian perspective. Oxford: Clarendon Press.

Illife, John 1983. The emergence of African capitalism. Minneapolis: University of Minnesota Press.

International Labour Organization, Food and Agriculture Organization, International Union of Food, Agricultural, Hotel, Restaurant, Catering, Tobacco and Allied Workers' Associations. 2007. Agricultural workers and their contribution to sustainable agriculture and rural development. Geneva: ILO. http://www.faoilo.org/fileadmin/user_upload/fao_ilo/pdf/engl_agricultureC4163. pdf.

Jaffee, S. 1994. Contract farming in the shadow of competitive markets: The experience of Kenyan horticulture. In Living under contract: Contract farming and agrarian transformation in Sub-Saharan Africa, ed. P. Little and M. Watts, 97-139. Madison: University of Wisconsin Press.

Jayne, T.S., J. Chamberlin, and D. Headey. 2014. Land pressures, the evolution of farming systems, and development strategies in Africa: A synthesis. Food Policy 48: 1-17.

Kanogo, T. 1987. Squatters \& the roots of Mau Mau: 1905-63. Athens: Ohio University Press. Kitching, G. 1980. Class and economic change in Kenya. New Haven and London: Yale University Press.

Lamont, M. 1999. Not yet soko uhuru: The local appropriation of free market discourse in the coffee industry of rural Kenya, Meru District. Masters Thesis, Concordia University, Montreal Canada. 
Lele, U. and M. Agarwal. 1989. Smallholder and large-scale agriculture in Africa: Are there trade-offs between growth and equity? Discussion Paper 6. Washington, DC: The World Bank.

Leo, C. 1984. Land and class in Kenya. Toronto: University of Toronto Press. Leo, C. 1989. Land and class in Kenya. Harare: Nehanda Publishers.

Leys, C. 1975. Underdevelopment in Kenya: The political economy of neo-colonialism. London: Heinemann.

Li, T. 2011. Centering labor in the land Grab debate. Journal of Peasant Studies 38, no. 2: 281-98. Lincoln, D. 1994. Women mini-farmers in the South African tea industry. Development Southern Africa 11, no 4: 573-586.

Lipton, M. 2006. Can small farmers survive, prosper, or be the key channel to cut mass poverty? Journal of Agricultural and Development Economics 3, no 1: 58-85.

Lofchie, M.F. 1986. Kenya's agricultural success. Current History 5, 221-26.

Lofchie, M.F. 1989. The policy factor: Agricultural performance in Kenya and Tanzania. New York: Lynne Rienner.

Maertens, M. and J.F.M. Swinnen. 2009. Trade, standards and poverty: Evidence from Senegal. World Development 37, no 1: 161-178.

Mate, R. 2001. Land, women and sugar in Chipiwa. In Women, men and work: Rural livelihoods and south-eastern Zimbabwe, ed. P. Hebinck and M. Bourdillon, 37-59. Harare: Weaver Press.

McCarthy, J.F. 2010. Processes of inclusion and adverse incorporation: Oil palm and agrarian change in Sumatra, Indonesia. The Journal of Peasant Studies 37, no. 4: 821-50.

McCarthy, Nancy. 1999. Commercial ranches, traditional pastoralism: Comparing the systems through the drought cycle. Meeting on Rethinking Livestock Development, Tegemeo Institute, Isiolo, June 6-8.

McCulloch, N. and M. Ota. 2002. Export Horticulture and Poverty in Kenya. Working Paper No. 174. Institute of Development Studies. http://www.eldis.org/fulltext/mcculloch_neil_export_horticulture_2002.pdf.

Ndalilah, J.W. 2012. Colonial capitalism and the making of wage labour in Kimilili, Kenya: 1900-1963. International Journal of Humanities and Social Science 2, no. 23: 28290.

Njonjo, A.L. 1981. The Kenya peasantry: A re-assessment. Review of African Political Economy 8: 27-40.

Ng'ang'a, D.M. 1981. What is happening to the Kenyan peasantry? Review of African Political Economy 8: 7-16.

Orvis, S. 1993. The Kenyan Agrarian debate: A reappraisal. African Studies Review 36, no. 3: 23-48. Oya, C. 2007. Stories of rural accumulation in Africa: Trajectories and transitions among rural capitalists in Senegal. Journal of Agrarian Change 7, no. 4: 453-93.

Oya, C. 2010. Rural inequality, Wage employment and labour market formation in Africa: Historical and microlevel evidence. Working Paper No. 97. Policy Integration Department, International Labour Office. http://eprints.soas.ac.uk/10308/1/wcms_145084.pdf. 
Papenfus, M.M. 2000. Investing in oil Palm: An analysis of independent smallholder oil Palm adoption in Sumatra, Indonesia. Southeast Asia Policy Research, Working Paper, No. 15. Bogor: International Centre for Research in Agroforestry Southeast Asia.

Richardson, B. 2010. Big Sugar in southern Africa: Rural development and the perverted potential of sugar/ethanol exports. The Journal of Peasant Studies 37, no. 4: 917-38.

Rono, J.K. 2002. The impact of structural adjustment programmes on Kenya society. Journal of Social Development in Africa 17, no. 1: 81-98.

Sitko, J.N. and S.T. Jayne. 2014. Structural transformation or elite land capture? The growth of "emergent" farmers in Zambia. Food Policy 48: 194-202.

Smalley, R. 2013. Plantations, contract farming and commercial farming areas in Africa: A comparative review, Working Paper 55. Brighton: Future Agricultures Consortium.

Swainson, N. 1980. The rise of corporate capitalism in Kenva. 1918-1977. London: Heinemann.

Thurston, A. 1987 Smallholder agriculture in colonial Kenya: The official mind and the swynnerton plan. Cambridge African Monographs 8. Cambridge: African Studies Centre.

Velte, M. and P. Dannenberg. 2014. Export horticulture - Empowering female small-scale farmers in Kenya? Journal of the Geographical Society of Berlin 145, no 3: 135-141.

White, J. and B. White 2012. The new enclosures: Critical perspectives on corporate land deals. The Journal of Peasant Studies 39, no. 3-4: 619-647.

World Bank. 2011. Rising global interest in farmland: Can it yield sustainable and equitable benefits? Washington, DC: World Bank. 